While moving along the milk-conducting systems in a milking machine, milk is in contact with the inner surface whose area exceeds $20 \mathrm{~m}^{2}$. That leads to the formation of protein-fat biofilms of contamination, which are a nutrient medium for the development of microorganisms. With insufficiently effective cleaning of these contaminants, in the periods between milking, the number of microflorae located in milk-conducting systems increases by tens of thousands of times.

When cleaned with ineffective cleaning agents, mineral elements from milk are adsorbed on the surface of a protein-fat bio-film, which are subsequently compacted, changed, and converted into milk stone. In this case, the technical implementation of milk conducting systems is of critical importance.

It has been established that a milk line made from any material is better cleaned with a hot washing solution than a cold one. Thus, with an increase in the temperature of a washing solution from $60^{\circ} \mathrm{C}$ to $85^{\circ} \mathrm{C}$, the cleaning time of the milk line is reduced from 9.5 minutes to 1.5 minutes, or by 6 times.

It was established that during the washing phase of a milk line there is a significant decrease in the temperature of the washing solution ( $\approx 30 \%)$, which reduces the effectiveness of cleaning the parts of the system. Therefore, there is a need to maintain the solution temperature throughout the entire cleaning process.

It is proved that the specific energy of adhesion of pollution in water is 2 times higher than that in a washing solution. With an increase in the temperature of the solution for every $10^{\circ} \mathrm{C}$, the decrease in the specific energy of pollution adhesion is on average $13 \%$. With an increase in the period after the end of milking before washing the milk line, the specific energy of its purification increases.

The study reported here could lead improve the productivity of milking machines and the quality of the resulting product. That involves designing milking and dairy equipment from innovative materials

Keywords: milking equipment, cleaning process, washing a milk line, washing solution, pollution adhesion
UDC 631.3 .636

DOI: $10.15587 / 1729-4061.2021 .237070$

\section{DETERMINING THE EFFICIENCY OF CLEANING A MILK LINE MADE FROM DIFFERENT MATERIALS FROM CONTAMINANTS}

\author{
Andriy Paliy \\ Corresponding author \\ Doctor of Agricultural Sciences, Associate Professor \\ Department of Technical Systems and Technologies of Animal Husbandry \\ Kharkiv Petro Vasylenko National Technical University of Agriculture \\ Alchevskih str., 44, Kharkiv, Ukraine, 61002 \\ E-mail: paliy.andriy@ukr.net \\ Elch y n A I i e v
}

Doctor of Technical Sciences, Professor, Senior Researcher Department of Mechanization of Production Processes in Animal Husbandry Dnipro State Agrarian and Economic University Sergei Efremov str., 25, Dnipro, Ukraine, 49600

Anatoliy Paliy

Doctor of Veterinary Sciences, Professor Laboratory of Veterinary Sanitation and Parasitology National Scientific Center «Institute of Experimental and Clinical Veterinary Medicine» Pushkinska str., 83, Kharkiv, Ukraine, 61023

O leks a ndr N e ch y orenko $\mathrm{PhD}$, Associate Professor Department of Therapy, Pharmacology, Clinical Diagnostics and Chemistry* Yuliia Baidevliatova $\mathrm{PhD}$, Senior Lecturer Department of Virusology, Patanatomy and Bird Diseases Named After Professor I. I. Panicar*

Yurii Baydevliatov $\mathrm{PhD}$, Associate Professor Department of Episootology and Parasitology*

Andrey Lazorenko $\mathrm{PhD}$, Associate Professor Department of Obstetrics and Surgery*

Vitali Ukhovskyi Doctor of Veterinary Sciences, Professor**

Leonid Korniienko

Doctor of Veterinary Sciences, Professor**

Pavlo Sharandak

Doctor of Veterinary Sciences, Associate Professor «Ukrvetprompostach» LLC

Helsinskoi hrupy str., 23A, Brovary, Ukraine, 07403

* Sumy National Agrarian University Herasym Kondratiev str., 160, Sumy, Ukraine, 40021

**Department of Epizootology

State Scientific and Research Institute of Laboratory Diagnostics and Veterinary and Sanitary Expertise

Donetska str., 30, Kyiv, Ukraine, 03151
Received date 12.04.2021 Accepted date 09.07.2021 Published date 13.07.2021
How to Cite: Paliy, A., Aliiev, E., Paliy, A., Nechyporenko, O., Baidevliatova, Y., Baydevliatov, Y., Lazorenko, A., Ukhovskyi, V., Korniienko, L., Sharandak, P. (2021). Determining the efficiency of cleaning a milk line made from different materials from contaminants. Eastern-European Journal of Enterprise Technologies, 4 (1 (112)), 76-85. doi: https://doi.org/10.15587/ 1729-4061.2021.237070

\section{Introduction}

The milk that is obtained when sanitary production regimes are violated, in addition to increased bacterial con- tamination, has a very low degree of mechanical purity. As a result of the intensive activity of microflora that secretes lactic acid, the acidity of such raw materials during storage increases dramatically. The density of milk, in this case, 
decreases due to the transition of part of denser lactic sugar to a less dense lactic acid. Consequently, the milk obtained when sanitary and hygienic production regimes are not complied with cannot meet the requirements for any of the indicators put forward by processing enterprises to high-quality raw materials [1-3].

The sanitary and hygienic quality of milk production is an integrated issue, predetermined by a number of factors that are united by the concept of the «technology and culture of production». However, it is possible to distinguish the factor that exerts a dominant effect on quality, which is the sanitary and hygienic condition of milking equipment [4].

At present, the manufacturing of high-quality, safe milk involving modern high-tech means and methods [5] is considered relevant.

In addition, one of the important issues is the lack of information on the effects of washing solutions on milking and dairy equipment, in particular milk lines of various designs.

Thus, the current study needs to establish the effectiveness of cleaning milking and dairy equipment from contamination in milk lines with different structures.

Such an approach would make it possible to carry out effective cleaning of milking and dairy equipment. That could increase the performance of milking machines and the quality of the resulting product. In addition, this would make it possible to reveal the mechanism of interaction between pollution and the inner surface of a milk line, which is both theoretically and practically interesting.

\section{Literature review and problem statement}

Milking equipment is polluted mainly by milk fat and protein. Fat is not only firmly held on the surface but also contributes to the gluing of protein and mineral milk particles. Holding the contamination on the equipment depends on the materials from which it is made, as well as on the quality of surface finishing (its roughness). Pollution is longer maintained on aluminum and plastic equipment, less - on glass and stainless steel. Materials with a smooth surface demonstrate the least gluing of pollution particles, with porous and rough - the largest. The residues of fat are easily adsorbed by the rubber parts of equipment [6]. Works [7, 8] note that if cleaning measures are not carried out in a timely manner, fat easily penetrates through the pores deep into the parts, which is why the loss of the primary properties of rubber elements occurs. The specified issue is of the scientifically applied nature as regards the operational duration of rubber elements.

Up to now, classical foundations of adhesion and moistening theory have been studied and developed. These include the nature of adhesion interaction, the dependence of adhesion on the properties of contacting hard surfaces, the parameters that characterize these processes, and some other phenomena in simple liquid media. However, natural milk is a complex liquid polydisperse system containing many interrelated structural formations in the form of fat balls of various sizes, milk bodies, proteins, colloidal particles, and ions of soluble salts.

In the case of careless and irregular washing of milking machines and dairy equipment, pollution is constantly accumulated and held so tightly that it is impossible to remove it without special agents [9]. This problem requires a scientific approach to solve it. That can be done by designing and applying the newest technological solutions to remove pollution and improve cleaning technologies.
Given a significant number of connections between milk lines, their small diameter, the distance from the milking machines in the milk transport chain, and the sharp bends of the profile, it is extremely difficult to maintain a satisfactory sanitary and hygienic condition of milking machines [10]. The difficulties in cleaning, as indicated in work [11], involve the use of plastic and rubber connecting pipes, air access to a closed milking and transportation system, insufficient volume of the collector's receiving chamber. Along with this, a strong hydrodynamic effect exerted on milk in the process of transportation through a milk line, the absence of a washing device for the cooling tank, and many other factors contribute to the intensive formation of heavy pollution.

The efficiency of washing is achieved at such a flow rate of the washing solution that is enough for the flow to detach and remove pollution particles, as indicated in [12]. In [13], it is emphasized that the flow rate value required to detach particles depends on their size, density, and shape, the roughness of the surface to be cleaned, the quality of a cleaning fluid, the magnitude of the liquefaction, the hydraulic parameters of a line, etc. At an unreasonably fast rate of fluid movement, energy costs for pumping the solution increase [14]. This issue is resolved with the introduction of advanced technological cleaning operations.

At the same time, in order to achieve maximum washing results, brushes of different models are used.

It should be noted that there is no consensus in relation to the flow rate of a washing solution, which would enable the most effective washing of milking machines.

In order to intensify the stirring of the solution, which has a significant impact on the rate of removal of contaminants, it is proposed to install special throttle washers in a milk line [15]. The intensity of stirring a washing solution and, therefore, the quality of washing, are effectively affected by flow pulsations created by various devices [16].

Fluid circulation modes are important for the effective washing of the system [17]. It has been proven in [18] that the high quality of cleaning can be achieved under the developed turbulent mode of the flow of a washing liquid at high speeds. In that case, the most favorable conditions for the mechanical effect of the flow on pollution particles are created. According to [19], the quality of washing milking machines is directly proportional to the temperature of a washing solution. With an increase in temperature, the physical and chemical activity of a washing solution increases, the energy of adhesion at the interphase decreases (washing solution - pollution), its kinematic viscosity decreases, and, as a result, turbulence increases [20]. It is also noted [21] that an increase in temperature above $60{ }^{\circ} \mathrm{C}$ does not cause a noticeable increase in washing properties; for this reason, the temperature regime of washing is close to that value. Of course, the temperature at different points of a milk line is not the same, it varies as the hot solution passes through it. If the system is closed and heat is not supplied externally, then the circulating solution is gradually cooled while the efficiency of washing is reduced.

However, in any case, it can be argued that the temperature regime is directly proportional to the temperature, the volume of the incoming solution, and the ambient temperature, and is inversely proportional to the length of a milk line.

The researchers' opinions on a temperature regime for washing the milking machines are different. Thus, work [22] states that effective washing is possible at a solution temperature not lower than $85^{\circ} \mathrm{C}$. At the same time, it is noted in work [23] 
that washing should be carried out at a solution temperature of $70-80^{\circ} \mathrm{C}$. Some firms (DeLava, BouMatic), engaged in the production of milking machines, recommend cleaning milk lines with solutions at a temperature not lower than $77^{\circ} \mathrm{C}$.

At the same time, researchers found that as the washing time increases, the cleaning quality improves. It has been proven [24] that the circulation washing of milk conducting systems with a significant number of parts and assemblies made of aluminum should last from 10 to 20 minutes. At the same time, manufacturers (GEA Farm Technologies, Lely) of milking and dairy equipment recommend processing time in the range of 5-30 minutes [25].

A cardinal way to maintain the necessary sanitary and hygienic condition of milking and dairy equipment is the use of highly effective means of sanitary treatment [26].

It is noted in [27] that for the sanitary treatment of milking machines, milk lines, and other technological milking and dairy equipment, drugs that have both detergent and disinfectant properties are increasingly used. There is a large amount of these means in the market, which predetermines a scientific study into their impact on milking and dairy equipment.

It is emphasized in [28] that the use of chemicals of various types depends on the method of washing. Disinfection can be carried out by special agents as a separate operation, or combined with a circulation washing if complex washing solutions are used. Acid can also be used as a disinfectant [29].

At present, highly effective washing, washing and disinfecting solutions, as well as modes of their use for sanitary treatment of the entire set of dairy equipment [30,31] have been developed. However, there is no single opinion on cleaning modes involving the use of modern washing solutions.

Consequently, the cleaning process is one of the most important technological operations, whose effectiveness affects the level of primary milk contamination.

Thus, resolving the issue related to improving the sanitary quality of milk necessitates research, revision, and improvement of key provisions and elements of the system of technological measures and technical means for servicing milking and dairy equipment. This is of both scientific and practical interest.

\section{The aim and objectives of the study}

The aim of this study is to establish the effectiveness of cleaning milking and dairy equipment from contamination for various designs of a milk line. This would improve the productivity of milking machines and the quality of the resulting product.

To accomplish the aim, the following tasks have been set:

- to experimentally establish the quality of cleaning milking and dairy equipment from contamination during its circulation washing;

- to determine the dynamics of change in the temperature of the liquid during its circulation in a milk line;

- to determine the specific energy of washing a milk line.

\section{The study materials and methods}

4. 1. Procedure for determining the quality of cleaning milking and dairy equipment from contamination during its circulation washing

We studied the quality of cleaning milking and dairy equipment from pollution in an industrial setting. The study factors selected are the material of milking and dairy equipment (stainless steel, polymer, rubber, glass, aluminum), the type of washing solution (sulfuric acid, Bluer solution, the alkaline solution CleanCowBASE based on sodium hydroxide and active chlorine), a washing solution temperature (from $60{ }^{\circ} \mathrm{C}$ to $85^{\circ} \mathrm{C}$ ), the flow rate of a washing solution (from $1 \mathrm{~m} / \mathrm{s}$ to $8 \mathrm{~m} / \mathrm{s}$ ).

The temperature of a washing solution was set using a heater and controlled by the DS18B20 temperature sensor. The flow rate of a washing solution was set by a pump and controlled by measuring the volumetric fluid consumption using the Elecrow liquid flow sensor, and subsequent recalculation. These sensors were connected to the Milking Machine Tester v. 2.0 (designed by E. B. Aliyev), shown in Fig. 1.

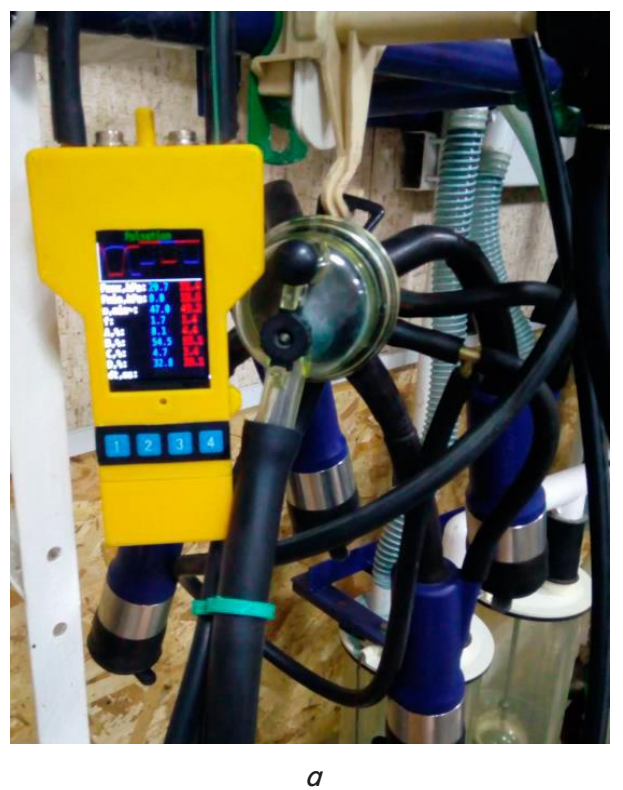

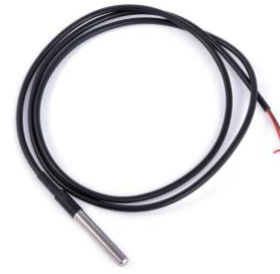

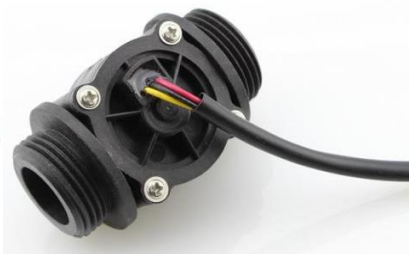

Fig. 1. Equipment used in the study: $a$ - Milking Machine Tester v. 2.0; $b$ - temperature sensor DS18B20; $c$ - Elecrow liquid flow sensor

In order to determine the quality of cleaning a milk line, we applied the designed device and appropriate procedure [32]. The designed device for determining the quality of washing (Fig. 2) is a tube installed in a straight section of the milk line with the help of connecting couplings. In the tube, a hole perpendicular to its axis is made, which is closed by a stopper with a subject plate fixed in it. On opposite sides of the subject plate, there is the light diode $1 \mathrm{~W} 100 \mathrm{Lm}$ (China) and the photoresistor FR1-3 (China), $47 \mathrm{kOhm}$, which, through the replaceable resistor $10 \mathrm{k} \Omega$, and a resistor of $10 \mathrm{kOhm}$, respectively, are connected to the board Arduino Uno (China). Arduino Uno is connected to a $12-24 \mathrm{~V}$ power supply via an external power connector, and connected to a personal computer via a USB connector. The personal computer runs software for fixing the voltage of an analog 
signal acquired from the photoresistor FR1-3. For a perfectly clean subject plate, fixed data correspond to $100 \%$. When milk passes through a milk line, the plate becomes dirty and the photoresistor F1-3 absorbs less light from the light diode of $1 \mathrm{~W} 100 \mathrm{Lm}$, thereby reducing the voltage value of the analog signal. For a completely impenetrable plate, the data corresponds to $26 \%$. This is due to the possibility of light bending the subject plate and reflecting it from the walls of the milk line. In turn, when passing the detergent through the milk line, the subject plate is cleaned, which makes it possible to increase the intensity of light absorption by the photoresistor FR1-3. The washing intensity was chosen as a criterion for assessing the quality of cleaning milking equipment from pollution. This indicator was determined as the duration of the process of cleaning the equipment to the predefined level of light passing through the subject plate to the photoresistor FR1-3 at the level not exceeding $95 \%$.

We controlled the degree of purification of the milk line during washing according to a procedure from [33]. The content of the protein components from the contaminants left in the milk line was controlled. The contaminants' residues were converted in the Bluer solution or solution of sulfuric acid depending on the milk line's material.
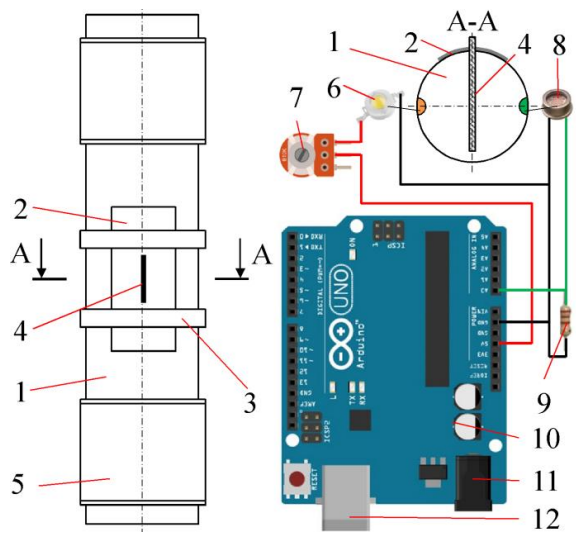

$a$

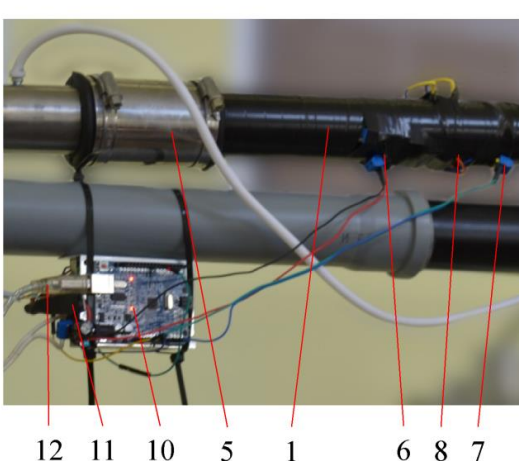

$b$
Fig. 2. Setup for determining the quality of washing a milk line: $a$ - structural diagram; $b$ - general view: 1 - section of the pipe; 2 - stopper; 3 - clamps for fastening the stopper; 4 - subject plate; 5 - connecting couplings; 6 - LED 1W $100 \mathrm{Lm} ; 7$ - alternating resistor $10 \mathrm{k} \Omega$; 8 - photoresistor FR 1-3 47 kOhm; 9 - resistor $10 \mathrm{kOhm}$; 10 - Arduino Uno board, external power connector $12-24 \mathrm{~V} ; 11-$ USB connector for connecting to a personal computer
4. 2. Procedure for establishing the dynamics of change in the temperature of the liquid during its circulation in a milk line

The efficiency of washing the milking and dairy equipment largely depends on the temperature of washing solutions and their stability during the washing time. In this regard, one of the areas of our research was to determine the dependence of the intensity of washing a milk line on the temperature of the washing solution.

The process of washing a milk line includes two temperature regimes. A first mode is enabled in the initial and final phase of washing when rinsing the milk line to wash off milk residues immediately after milking and after washing it with washing and disinfecting solutions. A second mode is enabled during the washing and disinfection phase with a pulsating air supply to it.

The temperature of the washing solution at different points of the milk production line was determined using the electronic thermometer TM-32/H-5T (Ukraine) equipped with a system of temperature probes based on the temperature sensors DS18B20. The electronic thermometer TM-32/H-5T was connected to a personal computer to acquire and process the data (Fig. 3 ).

Experiments were carried out in two stages.

At the first stage, the washing solution was not additionally heated during the circulation process. Data on the temperature of the solution and the flow rate of its circulation were measured every minute. The water consumption for washing ranged from 20-40 liters every 5 liters; the washing time - within 5-30 minutes every 5 minutes.

At the second stage, the tank was equipped with water heaters with a thermal relay, maintaining the temperature of the washing liquid with fluctuations within $\pm 1{ }^{\circ} \mathrm{C}$ from the established value.

In the experiments, we varied the temperature of water in the range of $55-85^{\circ} \mathrm{C}$ with an interval of $5^{\circ} \mathrm{C}$, as well as a washing time and water consumption within the same limits and intervals as in the first experiment.
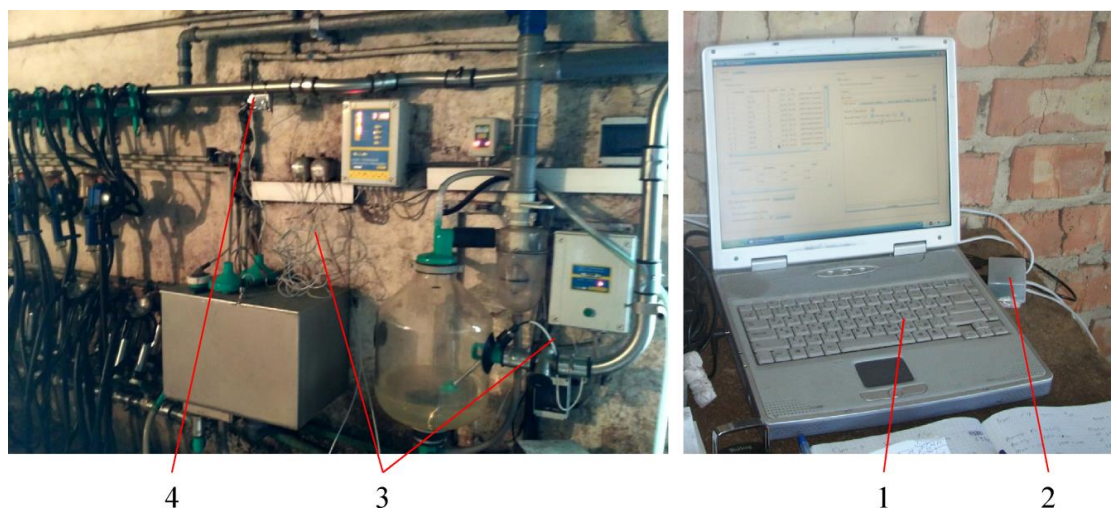

Fig. 3. Measuring the temperature and quality of milk line cleaning:

1 - personal computer; 2 - electronic thermometer TM-32/H-5T; 3 - a system of temperature probes based on temperature sensors DS18B20; 4 - a device for determining the quality of washing the milk line 
4. 3. Procedure for determining the specific energy of washing a milk line

The alkaline agent CleanCowBASE (Poland) and the PZ-chorolite 2000 by ECOLAB (Ukraine) were used as washing solutions to investigate the effect exerted on the specific energy of adhesion by the protein-fat contaminants of the milk line. The multiplicity of studies was taken equal to five $(n=5)$. The relative error of the average value of the measuring value was $\pm 1 \%$.

The adhesive strength of protein-fat contaminants was determined according to [28]. In line with that procedure, adhesion strength was determined taking into consideration the relief of the surface, the interphase surface energy, moistening, and other surface phenomena, as well as taking into consideration the conditions of contact formation (the pressure, temperature, duration of contact, etc.).

\section{The results of studying the effectiveness of cleaning milking and dairy equipment from contamination}

5. 1. Establishing the quality of cleaning milking equipment from contamination during its circulation washing

In our experiments on the quality of cleaning the insert into a milk line made from various materials, the best indicators of circulation washing at the generally accepted factory instructions of the cleaning regime (5 min preliminary washing +15 min circulation washing with CleanCowBASE +5 min final washing) were demonstrated by glass and stainless steel; the worst - by aluminum and a rubber product (Fig. 4).

Based on the results of processing data shown in charts in Fig. 4, the following regression equations were derived:

- stainless steel:

$$
\begin{aligned}
& t=-0.1198 \cdot T+10.214, \\
& R^{2}=0.9974
\end{aligned}
$$

- glass:

$$
\begin{aligned}
& t=-0.149 \cdot T+12.981 \\
& R^{2}=0.9949
\end{aligned}
$$

$$
\begin{aligned}
& \text { - polymers: } \\
& t=-0.1424 \cdot T+13.642, \\
& R^{2}=0.9936 ; \\
& - \text { rubber: } \\
& t=-0.1456 \cdot T+15.067, \\
& R^{2}=0.9893 ; \\
& - \text { aluminum: } \\
& t=-0.1049 \cdot T+13.825, \\
& R^{2}=0.9941,
\end{aligned}
$$

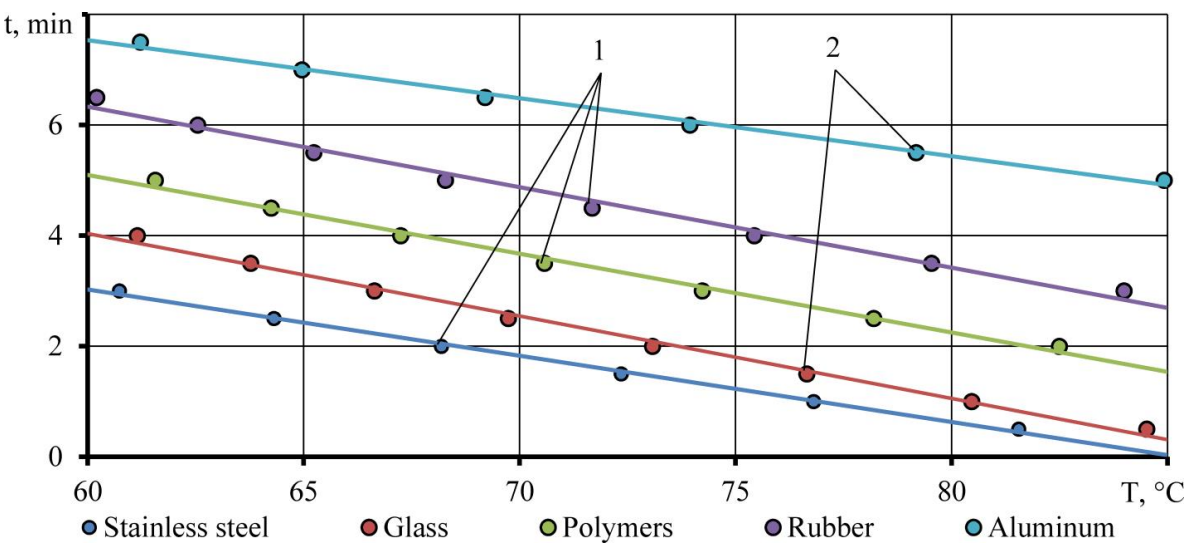

Fig. 4. Dependence of the duration of cleaning a milk line made from various materials on the temperature of a washing solution at its flow rate $V=2 \mathrm{~m} / \mathrm{s}$ : 1 - flushing of sulfuric acid; 2 - flushing of the Bluer solution

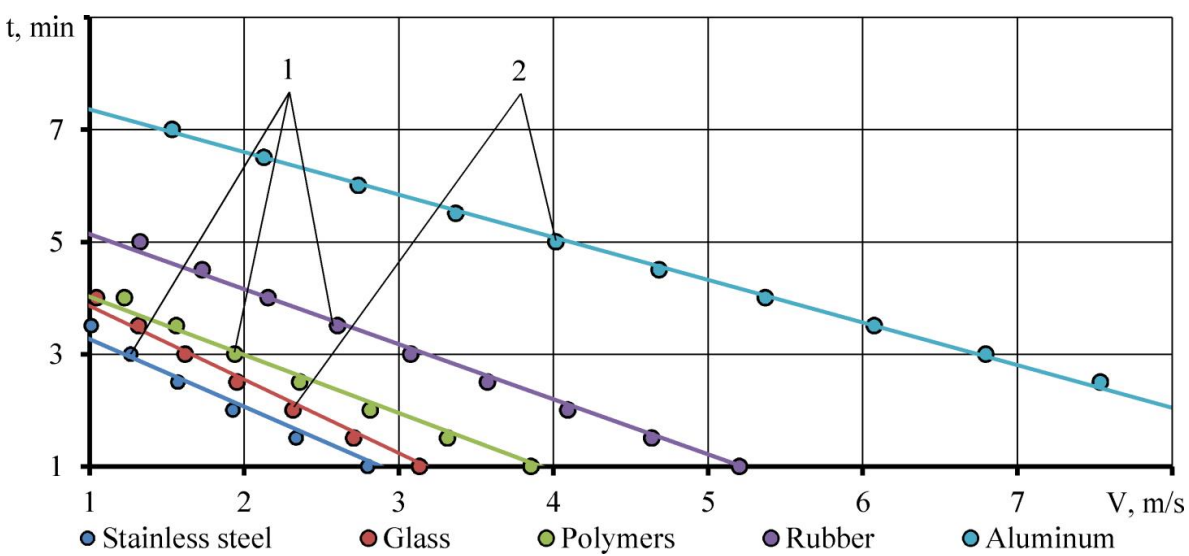

Fig. 5. Dependence of the duration of washing a milk line on the flow rate of washing solution at its temperature $T=80^{\circ} \mathrm{C}: 1-$ flushing of sulfuric acid; 2 - flushing of the Bluer solution where $T$ is the temperature of the washing solution, ${ }^{\circ} \mathrm{C}$; $t$ is the duration of cleaning the milk line, min.
A milk line made from any material is better cleaned during any washing with a hotter cleaner solution than with a cold one. Thus, with an increase in the temperature of the CowBASE washing solution from $60^{\circ} \mathrm{C}$ to $85^{\circ} \mathrm{C}$, the cleaning time of the milk line is reduced from 9.5 minutes to 1.5 minutes, or by 6 times.

In the experiments, the worst cleaned areas were those milk line sections (and, consequently, the parts of the milk line) that were made of food aluminum.

In the process of washing a milk line, the protein and mineral components are washed quite quickly, the fat comnents are harder to remove, especially in dried conglomerates. Under the action of the washing solution, fat pollutants are hydrolyzed more intensively with an increase in the the solution and the time of its circulation in the milk line. Dried areas of pollution and the film from it are removed mainly by high-speed pressure of the solution flow, ollowed by crushing during transportation.

According to data from Fig. 5, an increase in the rate of circulation of the washing solution in a milk line helps reduce the ness of its cleaning to the zoo-technical norms of cleanliand rubber are cleaned much longer. This is due not only to the significant roughness of their inner surfaces but also to stronger adhesion properties, which gives reason to recommend using them as parts of the dairy line only in extreme cases. 
The regression equations of the dependence of the duration of washing a milk line on the flow rate of a washing solution take the following form (Fig. 5):

- stainless steel:

$t=-1.2023 \cdot V+4.4727, R^{2}=0.9841$

- glass:

$t=-1.3106 \cdot V+5.1708, R^{2}=0.9917 ;$

- polymers:

$t=-1.0352 \cdot V+5.0576, R^{2}=0.9909 ;$

- rubber:

$t=-0.9799 \cdot V+6.1183, R^{2}=0.9958$

- aluminum

$t=-0.7589 \cdot V+8.1204, R^{2}=0.9985$.

Based on the results of our study, the rational modes for washing parts of a milk line made from various materials are within the limits specified in Table 1.

Table 1

Rational modes for washing a milk line made from various materials (by the agent CleanCowBASE)

\begin{tabular}{|c|c|c|c|}
\hline $\begin{array}{c}\text { Milk line section } \\
\text { material }\end{array}$ & $\begin{array}{c}\text { Washing solu- } \\
\text { tion tempera- } \\
\text { ture } T,{ }^{\circ} \mathrm{C}\end{array}$ & $\begin{array}{c}\text { Solution } \\
\text { flow rate } \\
V, \mathrm{~m} / \mathrm{s}\end{array}$ & $\begin{array}{c}\text { Washing duration } \\
\text { until good-quality } \\
\text { cleanliness } t, \text { min }\end{array}$ \\
\hline Stainless steel & $60.7-81.6$ & $1.0-3.9$ & $0.5-3.0$ \\
\hline Glass & $61.2-84.5$ & $1.0-4.1$ & $0.5-4.0$ \\
\hline Aluminum & $61.2-84.9$ & $1.0-7.5$ & $5.0-7.5$ \\
\hline Rubber & $60.2-84.0$ & $1.3-6.4$ & $3.0-6.5$ \\
\hline Polymer & $61.6-82.5$ & $1.2-5.1$ & $2.0-5.0$ \\
\hline
\end{tabular}

These are rational parameters. However, the fact that the upper part of a milk line is washed weaker by the flow of a washing fluid than the lower one is still not taken into consideration; it is cleaned of dirt worse due to this. This phenomenon can be eliminated by increasing the pulsation of the flux of a washing liquid under a stopper mode of the flow by a periodic supply of atmospheric pressure air to the milk line with the help of a pneumatic valve.

5. 2. Determining the dynamics of change in the temperature of the liquid during its circulation in a milk line

During the washing process, the temperature of the liquid at the end of the milk line depends mainly on the duration of rinsing (Table 2).

The output data were acquired when using modern equipment (Fig. 3).
Table 2

Effect of the time of rinsing a milk line in the first phase of washing on the temperature of the liquid discharged from it

\begin{tabular}{|c|c|}
\hline $\begin{array}{c}\text { Rinsing duration } \\
t_{\text {rinsing, }} \mathrm{s}\end{array}$ & $\begin{array}{c}\text { Water temperature at the system discharge } \\
\text { after rinsing } T_{\text {rinsing }},{ }^{\circ} \mathrm{C}\end{array}$ \\
\hline $60 \pm 2.5$ & $25 \pm 1$ \\
\hline $120 \pm 2.5$ & $27 \pm 1$ \\
\hline $180 \pm 2.5$ & $29 \pm 1$ \\
\hline $240 \pm 2.5$ & $32 \pm 1$ \\
\hline $300 \pm 2.5$ & $35 \pm 1$ \\
\hline
\end{tabular}

With a reduction in the duration of rinsing a milk line, the water temperature at the outlet from the system decreases by almost 1.5 times. At the same time, a significant part of the heat is spent on heating the milk line's parts. With a further increase in the duration of rinsing to 5 minutes, the water temperature at discharge rises to $35^{\circ} \mathrm{C}$.

This pattern of change in the temperature of washing water was observed at different water temperatures: $20,30,40^{\circ} \mathrm{C}$. Water with a higher temperature in the initial washing phase was not used as this adversely affects the quality of the rinsing process and the washing off of protein components of pollution.

Reducing the temperature of the water during rinsing after a circulation washing is less significant. This is because heat loss on heating parts of the system is reduced.

For the high-quality washing and disinfection phase, it is necessary to maintain the stability of the temperature regime during the circulation of the solution along the entire length of the milk line.

In the experiments, we used the detergent CleanCowBASE. The initial temperature of the solution was taken equal to 60,70 , and $80^{\circ} \mathrm{C}$, the temperature in the room was $24^{\circ} \mathrm{C}$. In the first series of experiments, the washing solution was not heated in the studied system. The results of measurements at the initial temperature of $70^{\circ} \mathrm{C}$ are shown in Fig. 6; the corresponding approximated equations are:

- heated:

$T=-6.937 \cdot \ln (t)+102.18, R^{2}=0.9949 ;$

- not heated:

$T=-9.192 \cdot \ln (t)+112.05, R^{2}=0.9977$.

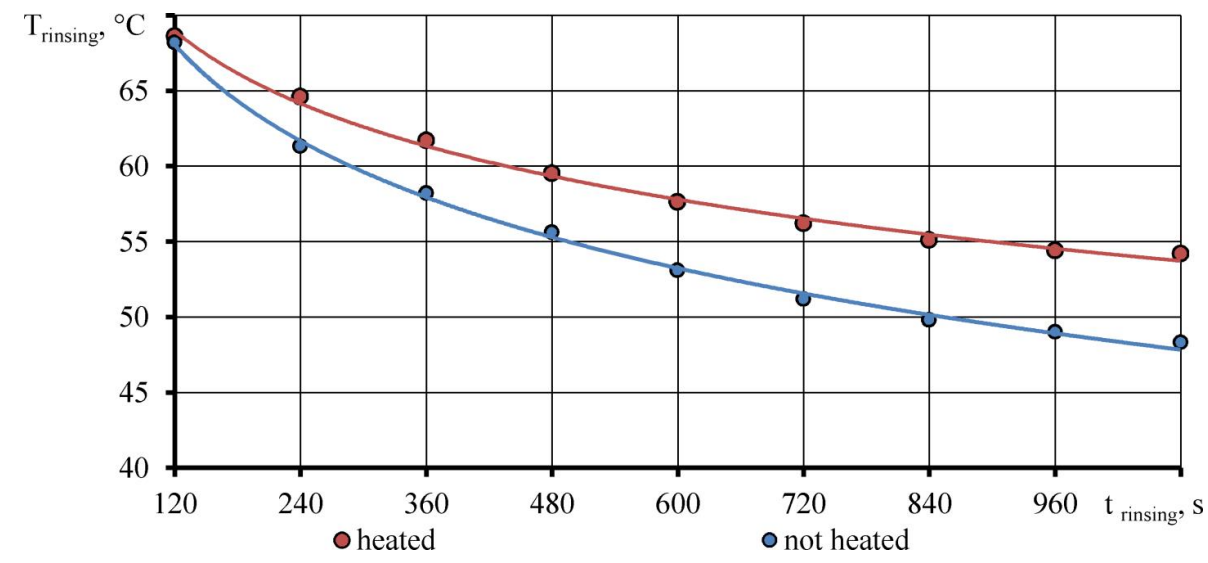

Fig. 6. Regularities of change in the temperature of a washing solution during its circulation 
During a milk line washing phase, there is a significant decrease in the temperature of the washing solution $(\approx 30 \%)$, which reduces the efficiency of cleaning the parts of the system. Therefore, there is a need to maintain the temperature within certain limits in order to improve the quality of washing. This can be done with the help of built-in electric heaters.

Further experiments involved heating a washing solution using electric heaters in the intake tank to a temperature of $70^{\circ} \mathrm{C}$. When using electric heaters, the temperature of the washing solution when discharged into the bath is higher than in the first experiments without heating the solution.

That makes it possible to wash the milk line more intensively, however, its washing modes can be different both in terms of washing duration and in terms of the flow rate and its temperature.

\section{3. Determining the specific energy of washing a} milk line

Energy costs for cleaning a milk line depend on the adhesion of protein and fat contaminants to its inner surface. The specific energy of adhesion in the dairy line used is directly dependent on the material of the parts of this line, the properties of pollutants, the composition of the detergent, and its temperature.

The estimated values (based on [28]) for the specific energy of adhesion of protein-fat contaminants to the milk line made from various materials, given in Table 3 , show that its value decreases with an increase in the temperature of the detergent solution. This decrease is on average $13 \%$ for every $10{ }^{\circ} \mathrm{C}$ increase in the temperature of the solution.

Table 3

Influence of the temperature of detergent solutions on the specific energy of adhesion of protein-fat contaminants in a milk line

\begin{tabular}{|c|c|c|c|c|c|c|}
\hline \multirow{2}{*}{$\begin{array}{c}\text { Milk line } \\
\text { material }\end{array}$} & \multicolumn{5}{|c|}{ Washing solution temperature, ${ }^{\circ} \mathrm{C}$} \\
\cline { 2 - 7 } & $60 \pm 1$ & $70 \pm 1$ & $80 \pm 1$ & $60 \pm 1$ & $70 \pm 1$ & $80 \pm 1$ \\
\cline { 2 - 7 } & \multicolumn{5}{|c|}{ Adhesion specific energy, $10^{-3} \mathrm{~J} / \mathrm{m}^{2}$} \\
\hline Stainless steel & $2.7 \pm 0.1$ & $2.2 \pm 0.1$ & $2.0 \pm 0.1$ & $3.0 \pm 0.1$ & $2.5 \pm 0.1$ & $2.2 \pm 0.1$ \\
\hline Aluminum & $7.5 \pm 0.2$ & $6.2 \pm 0.3$ & $5.5 \pm 0.3$ & $7.9 \pm 0.4$ & $7.4 \pm 0.4$ & $7.0 \pm 0.3$ \\
\hline Rubber & $5.7 \pm 0.4$ & $4.6 \pm 0.1$ & $4.2 \pm 0.3$ & $6.1 \pm 0.3$ & $5.3 \pm 0.2$ & $4.7 \pm 0.2$ \\
\hline Glass & $4.8 \pm 0.2$ & $3.9 \pm 0.1$ & $3.5 \pm 0.1$ & $5.2 \pm 0.3$ & $4.5 \pm 0.1$ & $4.1 \pm 0.2$ \\
\hline
\end{tabular}

The specific energy of the pollutant adhesion in water is almost 2 times higher than that in the washing solution, which explains the poor cleaning of milk lines with clean water.

With an increase in the period after the end of milking cows before washing the milk line, the specific energy of its purification increases (Fig. 7).

The corresponding approximated equations are: - stainless steel:

$W=0.0017 \cdot t^{2}-0.0518 \cdot t+3.2167, R^{2}=0.9948$,

- rubber:

$W=0.0013 \cdot t^{2}+0.0103 \cdot t+7.0524, R^{2}=0.996$.

That increase is critically important at long intervals before washing a milk line and, especially, for its sections made of hard-to-wash materials. This indicates the inadmissibility of significant deferrals in the care of the dairy milking line after milking cows.

\section{Discussion of results of studying the effectiveness} of cleaning milking and dairy equipment

Our analysis of numerous experiments [34-36] reveals that cleaning milking and dairy equipment from contamination affects the quality of the resulting product and the performance of equipment stronger than any other factor.

At the initial stage of research, it was intended to determine the quality of cleaning milking and dairy equipment from contamination during its circulation washing. During the research, the original procedure was used, which involved the use of an innovative device (Fig. 2). Based on the results of our study, the rational modes for washing parts of a milk line (Table 1) have been established. The reported results reveal the mechanism of interaction between a washing agent and elements of milking and dairy equipment, which are made of various materials. Thus, we have established the dependence of the duration of cleaning a milk line made from various materials on the temperature of the washing solution (Fig. 4) and the dependence of the duration of washing a milk line on the flow rate of a washing solution (Fig. 5). Owing to this, the issue related to the rational selection and use of washing solutions is resolved.

In works [37,38], it is noted that the effectiveness of washing milking and dairy equipment is significantly influenced by the roughness of the material from which the milk line is made, as well as microbial adhesion. The advantages of our study compared to those cited are to identify differences in the cleaning of elements of milking equipment made of various materials. That fully reveals the pattern of the process of cleaning milking and dairy equipment. 
At the next stage, we determined the dynamics of change in the temperature of the liquid during its circulation in a milk line. Fig. 3 shows the innovative technical solution used. Our study has established the effect of the time of rinsing a milk line in the first phase of washing on the temperature of the liquid discharged from it (Table 2), as well as the pattern of change in the temperature of a washing solution during its circulation (Fig. 6). Our results expand the understanding of processes that occur during the washing of a milk production line and make it possible to detect their effect on the temperature indicators of the washing solution.

In work [39], attention is paid to the fact that improper cleaning of milking and dairy equipment can lead to a significant deterioration in the milk produced. The current research confirms this theory, make it possible to take a critical approach to the issue of technical maintenance of dairy equipment.

Next, we determined the specific energy in washing a milk line. Thus, the estimated values of the specific energy of adhesion of protein-fat contaminants to a milk line made from various materials (Table 3 ) have been derived. It was established that with an increase in the period after the end of milking cows before washing the milk line, the specific energy of its purification increases (Fig. 7). Our study shows that it is unacceptable to allow significant delays in the care of the milking line of the milking plant after milking cows.

The study reported here differs favorably among others [40-42] by the complexity, the application of innovative approaches, and scale. At the same time, given the considerable variability of structural materials inherent in the milking equipment, there are difficulties in solving the issue of complete cleaning from pollution. This remains a problematic part of the overall technological process of obtaining high-quality milk.

The results of the research are consistent with the studies by other authors, carried out earlier in the field of development of technical and technological means and technologies for dairy cattle breeding [43-45], and complement them. A significant difference in the methodological plan of our research was that the parameters that affect the efficiency of cleaning milking and dairy equipment from contamination were taken into consideration as much as possible. This has created the opportunity to study and substantiate the optimal parameters for cleaning dairy equipment.

The limitation of the results is the difficulty in establishing the effectiveness of cleaning milk conducting systems when using modern washing solutions. The availability of a large number of means today predetermines further detection of their effective action.

Given a wide range of means for cleaning milking and dairy equipment, it becomes necessary to carry out further research in the field of selection of washing solutions. Therefore, it is promising to undertake a study aimed at establishing the mechanism of interaction of milking equipment elements with modern cleaning products. That would make it possible to expand the area of both theoretical and practical knowledge in dairy cattle breeding, which could serve as a prerequisite for the rational utilization of milking equipment.

\section{Conclusions}

1. A milk line made from any material is better cleaned with a hot cleaner solution than with a cold one. Thus, with an increase in the temperature of the washing solution from $60{ }^{\circ} \mathrm{C}$ to $85^{\circ} \mathrm{C}$, the cleaning time of a milk line is reduced from 9.5 minutes to 1.5 minutes, or by 6 times.

2. During the washing phase of a milk line, there is a significant decrease in the temperature of the washing solution $(\approx 30 \%)$, which reduces the efficiency of cleaning the parts of the milking system.

3. The specific energy of adhesion pollution in water is 2 times higher than that in a washing solution. With an increase in the temperature of the solution for every $10^{\circ} \mathrm{C}$, the decrease in the specific energy of pollution adhesion is on average $13 \%$. With an increase in the period after the end of milking cows before the milking system is washed, the specific energy of its purification increases.

\section{References}

1. Hogenboom, J. A., Pellegrino, L., Sandrucci, A., Rosi, V., D’Incecco, P. (2019). Invited review: Hygienic quality, composition, and technological performance of raw milk obtained by robotic milking of cows. Journal of Dairy Science, 102 (9), 7640-7654. doi: https://doi.org/10.3168/jds.2018-16013

2. Islam, M., Islam, M., Khan, M., Rashid, M., Obaidullah, S. (1970). Effect Of Different Hygenic Condition During Milking On Bacterial Count Of Cows' Milk. Bangladesh Journal of Animal Science, 38 (1-2), 108-114. doi: https://doi.org/10.3329/bjas.v38i1-2.9919

3. Bava, L., Zucali, M., Sandrucci, A., Brasca, M., Vanoni, L., Zanini, L., Tamburini, A. (2011). Effect of cleaning procedure and hygienic condition of milking equipment on bacterial count of bulk tank milk. Journal of Dairy Research, 78 (2), 211-219. doi: https://doi.org/ $10.1017 / \mathrm{s} 002202991100001 \mathrm{x}$

4. Pandey, N., Kumari, A., Varma, A. K., Sahu, S., Akbar, M. A. (2014). Impact of applying hygienic practices at farm on bacteriological quality of raw milk. Veterinary World, 7 (9), 754-758. doi: https://doi.org/10.14202/vetworld.2014.754-758

5. Paliy, A., Aliiev, E., Paliy, A., Ishchenko, K., Shkromada, O., Musiienko, Y. et. al. (2021). Development of a device for cleansing cow udder teats and testing it under industrial conditions. Eastern-European Journal of Enterprise Technologies, 1 (1 (109)), 43-53. doi: https://doi.org/10.15587/1729-4061.2021.224927

6. Krushelnytska, N. V. (2013). The influence of sanitary processing of milking equipment and milking technologies on hygienic quality of milk. Naukovyi visnyk Lvivskoho natsionalnoho universytetu veterynarnoi medytsyny ta biotekhnolohiy im. S. Z. Hzhytskoho, 15 (1 (55)), 93-97.

7. Paliy, A., Naumenko, A., Paliy, A., Zolotaryova, S., Zolotarev, A., Tarasenko, L. et. al. (2020). Identifying changes in the milking rubber of milking machines during testing and under industrial conditions. Eastern-European Journal of Enterprise Technologies, 5 (1 (107)), 127-137. doi: https://doi.org/10.15587/1729-4061.2020.212772 
8. Latorre, A. A., Van Kessel, J. S., Karns, J. S., Zurakowski, M. J., Pradhan, A. K., Boor, K. J. et. al. (2010). Biofilm in milking equipment on a dairy farm as a potential source of bulk tank milk contamination with Listeria monocytogenes. Journal of Dairy Science, 93 (6), 2792-2802. doi: https://doi.org/10.3168/jds.2009-2717

9. Paliy, A. (2016). Improvement technological method of cleaning milking dairy equipment. Naukovo-tekhnichnyi biuleten, 116, $104-108$.

10. Ohnstad, I. (2013). Effective cleaning of the milking machine. Livestock, 18 (1), 28-31. doi: https://doi.org/10.1111/ j.2044-3870.2012.00174.x

11. Wang, X., Demirci, A., Graves, R. E., Puri, V. M. (2019). Conventional and Emerging Clean-in-Place Methods for the Milking Systems. Raw Milk, 91-115. doi: https://doi.org/10.1016/b978-0-12-810530-6.00005-5

12. Zhmyrko, A. M. (2005). Kachestvo ochistki detaley molokoprovoda ot zagryazneniy pri ego tsirkulyatsionnoy moyke. Sovershenstvovanie protsessov i tekhnicheskih sredstv v APK, 6, 62-65.

13. Calcante, A., Tangorra, F. M., Oberti, R. (2016). Analysis of electric energy consumption of automatic milking systems in different configurations and operative conditions. Journal of Dairy Science, 99 (5), 4043-4047. doi: https://doi.org/10.3168/jds.2015-10490

14. Boguniewicz-Zablocka, J., Klosok-Bazan, I., Naddeo, V. (2017). Water quality and resource management in the dairy industry. Environmental Science and Pollution Research, 26 (2), 1208-1216. doi: https://doi.org/10.1007/s11356-017-0608-8

15. Aliyev, Y., Yaropud, V., Gavrilchenko, O., Kostenikov, O. (2019). Automated system of management of the technological process of milking. Engineering, Energy, Transport AIC, 3 (106), 5-12. doi: https://doi.org/10.37128/2520-6168-2019-3-1

16. Dmytriv, V. (2020). Model of forced turbulence for pulsing flow. Diagnostyka, 21 (1), 89-96. doi: https://doi.org/10.29354/diag/118651

17. Willers, C. D., Ferraz, S. P., Carvalho, L. S., Rodrigues, L. B. (2014). Determination of indirect water consumption and suggestions for cleaner production initiatives for the milk-producing sector in a Brazilian middle-sized dairy farming. Journal of Cleaner Production, 72, 146-152. doi: https://doi.org/10.1016/j.jclepro.2014.02.055

18. Kirsanov, V. V., Matveev, V. Yu. (2011). Energoeffektivnaya sistema promyvki molokoprovodov doil'nyh ustanovok. Tekhnika i oborudovanie dlya sela, $6,20-21$.

19. Santos, F. F., Queiroz, R. de C. S. de, Almeida Neto, J. A. de (2017). Evaluation of the application of Cleaner Production techniques in a dairy industry in Southern Bahia. Gestão \& Produção, 25 (1), 117-131. doi: https://doi.org/10.1590/0104-530x2234-16

20. Jones, G. M. (2009). Cleaning and Sanitizing Milking Equipment. Virginia Cooperative Extension, 400-404.

21. Vaughn, C. (2004). Successful CIP Cleaning. ASME 2004 Citrus Engineering Conference. doi: https://doi.org/10.1115/cec2004-5006

22. Alvarez, N., Daufin, G., Gésan-Guiziou, G. (2010). Recommendations for rationalizing cleaning-in-place in the dairy industry: Case study of an ultra-high temperature heat exchanger. Journal of Dairy Science, 93 (2), 808-821. doi: https://doi.org/10.3168/ jds.2009-2760

23. Fan, M., Phinney, D. M., Heldman, D. R. (2015). Effectiveness of Rinse Water during In-Place Cleaning of Stainless Steel Pipe Lines. Journal of Food Science, 80 (7), E1490-E1497. doi: https://doi.org/10.1111/1750-3841.12914

24. Palii, A. P. (2016). Innovations in ensuring the control of the purity of milk handling systems of milking machines. Tavriyskyi naukovyi visnyk, 95, 123-129.

25. Skarbye, A. P., Thomsen, P. T., Krogh, M. A., Svennesen, L., Østergaard, S. (2020). Effect of automatic cluster flushing on the concentration of Staphylococcus aureus in teat cup liners. Journal of Dairy Science, 103 (6), 5431-5439. doi: https://doi.org/10.3168/ jds.2019-17785

26. Paliy, A. P. (2016). Innovative approach in determining the action of washing solutions for treating milk leading systems. Tvarynnytstvo Ukrainy, 9-10, 11-13.

27. Memisi, N., Moracanin, S. V., Milijasevic, M., Babic, J., Djukic, D. (2015). CIP Cleaning Processes in the Dairy Industry. Procedia Food Science, 5, 184-186. doi: https://doi.org/10.1016/j.profoo.2015.09.052

28. Kukhtyn, M., Berhilevych, O., Kravcheniuk, K., Shynkaruk, O., Horyuk, Y., Semaniuk, N. (2017). The influence of disinfectants on microbial biofilms of dairy equipment. EUREKA: Life Sciences, 5, 11-17. doi: https://doi.org/10.21303/2504-5695.2017.00423

29. Verkholiuk, M. M., Peleno, R. A., Semaniuk, N. V. (2019). Development of a regime of disinfection of milking equipment and milk inventory with the acid detergent «Milkodez.» Scientific Messenger of LNU of Veterinary Medicine and Biotechnologies, 21 (96), 153-157. doi: https://doi.org/10.32718/nvlvet9627

30. Gleeson, D., O’Brien, B., Jordan, K. (2013). The effect of using nonchlorine products for cleaning and sanitising milking equipment on bacterial numbers and residues in milk. International Journal of Dairy Technology, 66 (2), 182-188. doi: https://doi.org/ 10.1111/1471-0307.12037

31. Ostrov, I., Harel, A., Bernstein, S., Steinberg, D., Shemesh, M. (2016). Development of a Method to Determine the Effectiveness of Cleaning Agents in Removal of Biofilm Derived Spores in Milking System. Frontiers in Microbiology, 7. doi: https://doi.org/ 10.3389/fmicb.2016.01498

32. Palij, A. (2016). Control of clearing of milk line on the basis of technological innovations. Visnyk Agrarnoi Nauky, 94 (10), 26-29. doi: https://doi.org/10.31073/agrovisnyk201610-05

33. Berezutskiy, V. I., Zhmyrko, A. M. (2001). Zakonomernosti izmeneniya temperaturnogo rezhima moyki molokoprovoda. Sovershenstvovanie protsessov i tekhnicheskih sredstv v APK, 3, 27-32.

34. Paliy, A (2015). Vstanovlennia chynnykiv, yaki vplyvaiut na protses promyvannia molokoprovodu. Visnyk Poltavskoi derzhavnoi ahrarnoi akademiyi, 1-2, 80-83. 
35. Marchand, S., De Block, J., De Jonghe, V., Coorevits, A., Heyndrickx, M., Herman, L. (2012). Biofilm Formation in Milk Production and Processing Environments; Influence on Milk Quality and Safety. Comprehensive Reviews in Food Science and Food Safety, 11 (2), 133-147. doi: https://doi.org/10.1111/j.1541-4337.2011.00183.x

36. Enokidani, M., Kawai, K., Shinozuka, Y., Kurumisawa, T. (2020). A case study of improving milking cow performance and milking system performance with using a flow simulator. Animal Science Journal, 91 (1). doi: https://doi.org/10.1111/asj.13389

37. Hocevar, M., Jenko, M., Godec, M., Drobne, D. (2014). An overview of the influence of stainless-steel surface properties on bacterial adhesion. Materials and technology, 48 (5), 609-617.

38. Hilbert, L. R., Bagge-Ravn, D., Kold, J., Gram, L. (2003). Influence of surface roughness of stainless steel on microbial adhesion and corrosion resistance. International Biodeterioration \& Biodegradation, 52 (3), 175-185. doi: https://doi.org/10.1016/ s0964-8305(03)00104-5

39. Paliy, A. (2016). Studying the process of pollution on milking dairy equpment. Tekhnolohiya vyrobnytstva i pererobky produktsiyi tvarynnytstva, 2 (129), 88-91.

40. Weber, M., Liedtke, J., Plattes, S., Lipski, A. (2019). Bacterial community composition of biofilms in milking machines of two dairy farms assessed by a combination of culture-dependent and -independent methods. PLOS ONE, 14 (9), e0222238. doi: https://doi.org/10.1371/journal.pone.0222238

41. Liu, Y., Wang, C., Shi, Z., Li, B. (2020). Optimization and Modeling of Slightly Acidic Electrolyzed Water for the Clean-in-Place Process in Milking Systems. Foods, 9 (11), 1685. doi: https://doi.org/10.3390/foods9111685

42. Monds, R. D., O’Toole, G. A. (2009). The developmental model of microbial biofilms: ten years of a paradigm up for review. Trends in Microbiology, 17 (2), 73-87. doi: https://doi.org/10.1016/j.tim.2008.11.001

43. Zheng, H., Jiménez-Flores, R., Everett, D. W. (2014). Lateral lipid organization of the bovine milk fat globule membrane is revealed by washing processes. Journal of Dairy Science, 97 (10), 5964-5974. doi: https://doi.org/10.3168/jds.2014-7951

44. Paliy, A. (2015). Analysis requirements for modes washing of milk milking machines. Visnyk Kharkivskoho natsionalnoho tekhnichnoho universytetu silskoho hospodarstva im. Petra Vasylenka, 157, 28-32.

45. Sutariya, S., Sunkesula, V., Kumar, R., Shah, K. (2018). Emerging applications of ultrasonication and cavitation in dairy industry: a review. Cogent Food \& Agriculture, 4 (1), 1549187. doi: https://doi.org/10.1080/23311932.2018.1549187 